\title{
Abdominal Fat by Imaging Methods and Metabolic Syndrome in Young People
}

\author{
Rommel Larcher Rachid Novais ${ }^{1}$, Ana Carolina Corrêa Café ${ }^{1}$, Wendell Costa Bila ${ }^{1}$, Gilson Donizette da Silva \\ Santos $^{1}$, Carlos Alexandre de Oliveira Lopes ${ }^{1}$, Márcia Christina Caetano Romano ${ }^{1 *}$ and Joel Alves Lamounier ${ }^{2}$ \\ ${ }^{1}$ Campus Centro-Oeste Dona Lindu da Universidade Federal de São João del Rei (UFSJ), Brazil
}

${ }^{2}$ Campus Dom Bosco da Universidade Federal de São João del-Rei (UFSJ), Brazil

Submission: November 7, 2017; Published: December 06, 2017

*Corresponding author: Márcia Christina Caetano Romano Rua Sebastião Gonçalves Coelho, 400 Bairro Chanadour Divinópolis, MG, Brazil, Tel: 55-37-988-075-388; Email: marciachristinacs@gmail.com

\begin{abstract}
Metabolic Syndrome is highlighted in the current health mainly due to its increasing prevalence in the world. Its occurrence among adolescents ranges from $2.2 \%$ to $51.7 \%$. This set of diseases, when acquired during childhood/adolescence, tends to persist into adulthood. This study aims to present the results of the latest publications that correlated ultrasonography, computed tomography and magnetic resonance imaging with the components of the Metabolic Syndrome in young people. Nine papers were found. Abdominal adipose accumulation has a strong influence on the metabolic disorders of MS, being measurable by imaging methods. It is of crucial importance to deepen the knowledge of the benefits brought by the imaging tests and their relationship with the components of the syndrome so that clinicians and radiologists can use these exams, especially in young people, where an accurate and early diagnosis allows interventions that will influence reducing the risk unfavorable outcomes in adult life.
\end{abstract}

Keywords: Metabolic syndrome X; Intra-abdominal fat; Computed tomography; Magnetic resonance imaging; Ultrasonography

Abbreviations: SM: Metabolic Syndrome; TM: Computer Tomography; RM: Magnetic Resonance Imaging; US: Ultrasonography; BVS: Health Virtual Library; CC: Waist Circumference; IMC: Body Mass Index; GAS: Subcutaneous Abdominal Fat; GAV: Visceral Abdominal Fat

\section{Introduction}

The Metabolic Syndrome (MS) has been gaining attention in the health scenario due to the increase of its prevalence in the world. Among the adolescents its prevalence has wide variation from $2.2 \%$ to $51.7 \%$ [1], being that its occurrence at this stage tends to persist into adulthood [2]. The central obesity is one of the key components of SM and it has been shown that the association between obesity and cardiovascular risk regarding the fat distribution. Subjects with abdominal obesity have a higher risk than those with gluteofemoral, peripheral or gynecoid obesity [3].

Imaging tests may contribute to the adipose tissue determination and characterization of the influence of the same in the pathophysiology of the syndrome, such as computed tomography (TM), magnetic resonance imaging (RM) and ultrasonography (US) [4-6]. The knowledge deepening on the aspects of the syndrome in young people is crucial, since precisely diagnosed; it enables interventions to reduce the risk of unfavorable outcomes in adult life. This literature review carried out in the databases Medline, through the Publisher Medline (Pubmed), Lilacs and Cochrane through the Health Virtual Library (BVS), with a time limit from 2010 to
2015, aims at evaluating studies that use imaging tests in the identification of metabolic syndrome and its components, with a focus on their employment and capacity for early detection of changes in abdominal fat in adolescents and young adults.

\section{Results}

Among the studies that comprise this literature review, there are five North American production [7-11], two Korean $[12,13]$, an article performed in conjunction between Denmark and Kenya [14] and a Brazilian article(15). Depending on the type of methodology applied in the selected articles, seven studies are cross-sectional and two of them have a methodology of cohort. All in all, the productions totalize 4670 subjects investigated as to associations of Metabolic Syndrome and the accumulation of adipose tissue. The ages mean ranged from 9.1 to 44.5 years.

Among the imaging exams are used to assess the intraabdominal fat, according to the studies analyzed, four (44.4\%) used the TM, four (44.4\%) RM and one (11.1\%) used the US, being observed correlation of three different types of imaging examinations with the SM. Among those who used RM and TC, three used as anatomical landmark for the 
images elaboration, the navel scar (28.30), four studies had as anatomical parameters of the fourth lumbar vertebra (L4) $[7,12]$ or the L4-L5 level $[9,10]$. An article, by using RM, based its image production based on the highest liver level up to the lower pole of the right kidney [8]. Finally, the study performed with the US [14], was carried out by using the standardized method of Stolk [6], which uses the midpoint between the inferior costal margin and the anterior- superior iliac crest as level for obtaining measurements. For correlation with methods that are more accessible and inexpensive of research, the anthropometric measurements of waist circumference (CC) and body mass index (IMC) were applied to the research obtained by means of the height and total body weight.

\section{Discussion}

The SM early diagnosis can determine actions aimed to prevent the future cardiovascular problems and their secondary psychosocial impairments $[15,16]$. The use of imaging examinations in the SM diagnosis is still little used in routine investigations. However, studies verified the relation of adipose tissue detected by imaging methods with the measurement of abdominal circumference and IMC. Katzmarzyk [9] points a lower correlation with the cardio metabolic risk, when compared with the CC and Visceral abdominal fat (GAV). According to Ali [7], this index shows a strong correlation with measures of central adiposity, fat distribution, dyslipidemia and insulin resistance.

CC was correlated most strongly with the deposit of subcutaneous abdominal fat (GAS) [7,8,17]. Harrington [8] sought the best anatomical reference for the CC evaluation, compared with the imaging exams, and found that the same does not exist, being suggested using the easiest identification points, avoiding some bone marks in children, due to their detection difficulty in obese individuals and due to its more embarrassing character [18]. There was a higher correlation of GAS with the Metabolic Syndrome during childhood, prevailing a mutual collaboration of GAS and GAV in adolescence, as verified by Spolidoro et al. [17], and transferring this responsibility to GAV in young adults, prevailing in adulthood [15]. The results suggest that the influence of body fat distribution in risk of Metabolic Syndrome is different in children and adolescents compared to adults. The deposit of intra-abdominal fat in adults would be the most significant parameter in terms of influence on insulin resistance and dyslipidemia, whereas in the case of children and adolescents it was identified that the deposit of subcutaneous fat is more related with these factors associated with the Metabolic Syndrome [19].There is still no unanimity in this relation, requiring further studies to determine the diagnosis $[7,17,20,21]$.

It was found only one study using ultrasonography. More studies should evaluate children and adolescents with this imaging test, since it is a useful examination in the direct evaluation of the deposit of abdominal fat, it does not use ionizing radiation and offers lower cost compared with magnetic resonance imaging and computed tomography, being widely accessible and non-invasive. Therefore, this method proves to be advantageous for large population studies and research related to the distribution of abdominal fat.

\section{Conclusion}

This review reveals a significant relation between abdominal fat measures through imaging examinations and the factors of the Metabolic Syndrome, especially the measurement of the thickness of subcutaneous adipose tissue in the lower age groups and the adipose intra-abdominal tissue in adolescents and young adults. Imaging tests have good applicability in the assessment of adipose tissue in young subjects, requiring further studies that adopt the ultrasonography in this evaluation and that can determine the cut-off diagnostics points for MS among children and adolescents, as already raised in adult subjects.

\section{References}

1. Traber MG (2014) Vitamin E inadequacy in humans: causes and consequences. Adv Nutr 5: 503-514.

2. Brion LP, Bell EF, Raghuveer TS (2003) Vitamin E supplementation for prevention of morbidity and mortality in preterm infants. Cochrane Database Syst Rev 4: CD003665.

3. Ochoa JJ, Ramirez-Tortosa MC, Quiles JL, Palomino N, Robles R, et al. (2003) Oxidative stress in erythrocytes from premature and full-term infants during their first $72 \mathrm{~h}$ of life. Free Radic Res 3: 317-322.

4. Fares S, Feki M, Khouaja-Mokrani C, Sethom MM, Jebnoun S, et al. (2014) Nutritional practice effectiveness to achieve adequate plasma vitamin A, E and D during the early postnatal life in Tunisian very low birth weight infants. J Matern Fetal Neonatal Med 10: 1-5.

5. Woods JR Jr, Cavanaugh JL, Norkus EP, Plessinger MA, Miller RK (2002) The effect of labor on maternal and fetal vitamins $\mathrm{C}$ and E. Am J Obstet Gynecol 187(5): 1179-1183.

6. Chai M, Barker G, Menon R, Lappas M (2012) Increased oxidative stress in human fetal membranes overlying the cervix from term nonlabouring and post labour deliveries. Placenta 33(8): 604-610.

7. Negi R, Pande D, Kumar A, Khanna RS, Khanna HD (2012) In-vivo oxidative DNA damage and lipid peroxidation as a biomarker of oxidative stress in preterm low-birthweight infants. J Trop Pediatr 58(4): 326-328.

8. Debier C, Larondelle Y (2005) Vitamins A and E: metabolism, roles and transfer to offspring. Br J Nutr 93(2): 153-174.

9. Debier C (2007) Vitamin E during pre-and postnatal periods. Vitam Horm 76: 357-373.

10. Bell EF (1987) History of vitamin E in infant nutrition. Am J Clin Nutr 46(1 Suppl): 183-186.

11. Gutcher GR, Raynor WJ, Farrell PM (1984) An evaluation of vitamin E status in premature infants. Am J Clin Nutr 40(5): 1078-1089.

12. Kitajima H, Kanazawa T, Mori R, Hirano S, Ogihara T, et al. (2015) Longterm alpha-tocopherol supplements may improve mental development in extremely low birth weight infants. Acta Paediatr 104(2): e82-e89.

13. Ortiz-Espejo M, Gil-Campos M, Mesa MD, García-Rodríguez CE, MuñozVillanueva MC, et al. (2014) Alterations in the antioxidant defense system in prepubertal children with a history of extra uterine growth restriction. Eur J Nutr 53(2): 607-615. 
14. Trindade CE, Rugolo LMSS (2013) Selenium and Vitamin A and E in the nutrition of very low-birth weight preterm infants. J Neonatal Biol 2(1): 1-7.

15. Fares S, Sethom MM, Khouaja-Mokrani C, Jabnoun S, Feki M, et al. (2013) Vitamin A, E, and D Deficiencies in Tunisian Very Low Birth Weight Neonates: Prevalence and Risk Factors. Pediatrics and Neonatology 55(3): 196-201.

16. Galinier A, Périquet B, Lambert W, Garcia J, Assouline C, et al. (2005) Reference range for micronutrients and nutritional marker proteins in cord blood of neonates appropriated for gestational ages. Early Hum Dev 81(7): 583-593.

17. MJ González-Corbella, MC López-Sabater, AI Castellote-Bargalló, C Campoy-Folgoso, M Rivero-Urgell (1998) Plasma and erythrocyte alpha-tocopherol and plasma retinol concentrations in term infants fed formula enriched with long-chain polyunsaturated fatty acids. Eur J Clin Nutr 52(11): 813-818.

18. Joshi SR, Mehendale SS, Dangat KD, Kilari AS, Yadav HR et al. (2008) High Maternal Plasma Antioxidant Concentrations Associated with Preterm Delivery. Ann Nutr Metab 53(3): 276-282.

19. Weber D, Stuetz W, Bernhard W, Franz A, Raith M (2014) Oxidative stress markers and micronutrients in maternal and cord blood in relation to neonatal outcome. Eur J Clin Nutr 68(2): 215-222.

20. Bell EF, Hansen NI, Brion LP, Ehrenkranz RA, Kennedy KA, et al. (2013) Serum tocopherol levels in very preterm infants after a single dose of vitamin E at birth. Pediatrics 132(6): e1626-e1633.

21. Henriksen C, Helland IB, Rønnestad A, Grønn M, Iversen PO, et al. (2006) Fat-soluble vitamins in breast-fed preterm and term infants. Eur J Clin Nutr 60(6): 756-762.

22. Koletzko B, Sauerwald U, Keicher U, Saule H, Wawatschek S, et al (2003) Fatty acid profiles, antioxidant status, and growth of preterm infants fed diets without or with long-chain polyunsaturated fatty acids: A randomized clinical trial. Eur J Nutr 42(5): 243-253.

23. Salle B (2007) Est-illégitime d'administrerdes vitamines liposolubles (A, E, D) chez leprématuré pendant 6 mois? Archives de Pédiatrie, 14(12): 1408-1412.

24. Turgut M, Bașaran O, Cekmen M, Karataș F, Kurt A, et al. (2004) Oxidant and antioxidant levels in preterm newborns with idiopathic hyperbilirubinaemia. J Paediatr Child Health 40(11): 633-637.

25. Chen K, Zhang X, Wei XP, Qu P, Liu YX, et al. (2009) Antioxidant vitamin status during pregnancy in relation to cognitive development in the first two years of life. Early Hum Dev 85(7): 421-427.

26. Institute of medicine (2000) Dietary reference intakes for vitamin C, vitamin E, selenium, and carotenoids. Food and Nutrition Board Washington, USA.

27. Niki E, Traber MG (2012) A history of vitamin E. Ann Nutr Metab 61(3): 207-212

28. El Euch-Fayache G, Bouhlal Y, Amouri R, Feki M, Hentati F (2014) Molecular, clinical and peripheral neuropathy study of Tunisian patients with ataxia with vitamin E deficiency. Brain 137(Pt 2): 402 410

29. Masters ET, Jedrychowski W, Schleicher RL, Tsai WY, Tu YH, et al (2007) Relation between prenatal lipid-soluble micronutrient status, environmental pollutant exposure, and birth outcomes. Am J Clin Nutr 86(4): 1139-1145.

30. da Silva Ribeiro KD, Lima MS, Medeiros JF, de Sousa Rebouças A, Dantas RC, et al. (2016) Association between maternal vitamin E status and alpha-tocopherol levels in the newborn and colostrum. Matern Child Nutr 12(4): 801-807.
31. Garcia L, Ribeiro K, Araújo K, Pires J, Azevedo G, et al. (2010) Alphatocopherol concentration in the colostrum of nursing women supplemented with retinyl palmitate and alpha-tocopherol. J Hum Nutr Diet. 23(5): 529-534.

32. Cristiane SSG, Larissa QL, Gabrielle MA, Priscila NC, Janaina OA et al. (2014) Comparison between the alpha-tocopherol serum concentration of assisted mothers in public and private maternity hospitals in the Northeast of Brazil. Rev Bras Ginecol Obstet 36(8): 3720-376

33. de Lira LQ, Lima MS, de Medeiros JM, da Silva IF, Dimenstein R (2013) Correlation of vitamin A nutritional status on alpha-tocopherol in the colostrum of lactating women. Maternal \& Child Nutrition 9(1): 31-40.

34. de Azeredo VB, Trugo NM (2008) Retinol, carotenoids, and tocopherols in the milk of lactating adolescents and relationships with plasma concentrations. Nutrition 24(2): 133-139.

35. Medeiros JF, da Silva Ribeiro Rodrigues KD, Lima MS, da Silva AL, de Queiroz JL, et al. (2016) Alpha-tocopherol concentration in colostrum and serum of women with premature labor. J Pediatr Gastroenterol Nutr 62(2): 348-352.

36. Ortega-Senovilla H, Alvino G, Taricco E, Cetin I, Herrera E (2009) Enhanced circulating retinol and non-esterified fatty acids in pregnancies complicated with intrauterine growth restriction. Clin Sci (Lond) 118(5): 351-358.

37. Schulpis KH, Michalakakou K, Gavrili S, Karikas GA, Lazaropoulou C et al. (2004) Maternal-neonatal retinol and alpha-tocopherol serum concentrations in Greeks and Albanians. ActaPaediatrica 93(8): 10751080 .

38. Lammi-Keefe CJ, Jonas CR, Ferris AM, Capacchione CM (1995) Vitamin $\mathrm{E}$ in plasma and milk of lactating women with insulin-dependent diabetes melittus. J Pediatr Gastroenterol Nutr 20(3): 305-309.

39. Papathakis PC, Rollins NC, Chantry CI, Bennish ML, Brown KH (2007) Micronutrient status during lactation in HIV-infected and HIVuninfected South African women during the first 6 mo after delivery. Am J Clin Nutr 85(1): 182-192.

40. Ortega RM, López-Sobaler AM, Martínez RM, Andrés P, Quintas ME (1998) Influence of smoking on vitamin E status during the third trimester of pregnancy and on breast-milk tocopherol concentrations in Spanish women. Am J Clin Nutr 68(3): 662-667.

41. Quiles JL, Ochoa JJ, Ramirez-Tortosa MC, Linde J, Bompadre S, et al (2006) Coenzyme Q concentration and total antioxidant capacity of human milk at different stages of lactation in mothers of preterm and full-term infants. Free Radic Res 40(2): 199-206.

42. Olafsdottir AS, Wagner KH, Thorsdottir I, Elmadfa I (2001) Fat-soluble vitamins in the maternal diet, influence of cod liver oil supplementation and impact of the maternal diet on human milk composition. Ann Nutr Metab 45(6): 265-272.

43. Martysiak-zurowska, D, Szlagatys-sidorkiewicz, A, Zagierski M (2013) Concentrations of alpha- and gamma-tocopherols in human breast milk during the first months of lactation and in infant formulas. Matern Child Nutr 9(4): 473-482.

44. Aubuchon-Endsley NL, Kennedy TS, Gilchrist M, Thomas DG, Grant S (2015) Relationships among socioeconomic status, dietary intake, and stress in breastfeeding women. J Acad Nutr Diet 115(6): 939-946.

45. Clemente, HÁ, et all (2014) Vitamin E in maternal serum and colostrum and the nutritional requirement of the infant. Modern Pediatrics 1:7580 .

46. Garcia LRS, da Silva Ribeiro KD, Katherine FA, Gabrielle MMA, JF Pires, et al. (2009) Levels of alpha-tocopherol in the serum and breast milk of 
puerperal patients attended at a public maternity hospital in Natal, Rio Grande do Norte. Rev Bras Health Mater Infant 9(4): 423-428.

47. Szlagatys-Sidorkiewicz A, Zagierski M, Jankowska A, Łuczak G, Macur $\mathrm{K}$, et al. (2012) Longitudinal study of vitamins A, E and lipid oxidative damage in human milk throughout lactation. Early Hum Dev 88(6): 421-424.

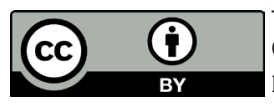

This work is licensed under Creative Commons Attribution 4.0 License DOI: $10.19080 / \mathrm{NFSIJ} .2017 .04 .555630$
48. Tijerina-sáenz A, Innis SM, Kitts DD (2009) Antioxidant capacity of human milk and its association with vitamins $\mathrm{A}$ and $\mathrm{E}$ and fatty acid composition. ActaPaediatrica 98(11): 1793-1798.

\section{Your next submission with Juniper Publishers will reach you the below assets}

- Quality Editorial service

- Swift Peer Review

- Reprints availability

- E-prints Service

- Manuscript Podcast for convenient understanding

- Global attainment for your research

- Manuscript accessibility in different formats

( Pdf, E-pub, Full Text, Audio)

- Unceasing customer service

Track the below URL for one-step submission https://juniperpublishers.com/online-submission.php 